資 料

\title{
原子カ・放射線関連用語に対する連想語の頻度分布に 基づいた概念の関連性の考察
}

\author{
占 部 逸 正 $^{*}$
}

(2001 年 8 月 9 日受理)

(2002 年 3 月 19 日再受理)

\section{Some Consideration on the Relevance of Concepts Based on the Probability Distribution of Words Reminded by Stimulus Terms Concerning Atomic Energy and Radiation Utilization}

Itsumasa URABE*1

\begin{abstract}
The relevance of concepts brought to mind by stimulus terms concerning atomic energy and radiation utilization has been investigated to learn how people understand the present status of nuclear technology. The relevance of concepts was defined as the frequency distribution of words that came to mind immediately after seeing selected terms needed for present-day life as well as for nuclear engineering. An analysis of knowledge structure shows that (1) a concept of atomic energy has a close relation with that of electric power generation; (2) an understanding of nuclear power utilization may be promoted in relation to an understanding of energy and environmental problems because the concepts of energy, atomic energy, electric power generation, and natural environment have closer relations with one another; (3) a concept of radiation has various relations with harmful radiological health effects, but little relation with industrial, agricultural, and other beneficial uses except for nuclear power generation or medical applications. It also became clear from the investigation that studies on natural radiation may be important to promote an understanding of radiation utilization because a concept of the natural environment does not yet relate to that of natural radiation.
\end{abstract}

KEY WORDS: relevance of concepts, nuclear engineering, atomic energy, electric power generation, radiation, natural environment

\section{I はじめに}

原子力や放射線の利用に際して，これらの活動により 生じる損害が，実際と大きく異なって評価された場合， 予期しない重大な事態や ICRP の言う有益な行為に対 する不当な制限が生じる可能性がある11。放射線の利用 に伴う被ばくの人への損害の可能性は, 他の有害な物質

*1 福山大学工学部; 広島県福山市学園町 1 番地（广 729-0292） School of Engineering, Fukuyama University; Gakuen-cho 1, Fukuyama, Hiroshima 729-0292, Japan.
に比べ高い確度で明らかにされているが，このことは危 険な事態や不当な制限の生じる可能性を著しく少なく し，原子力や放射線の適切な利用を可能にする基礎とな っている。しかし同時に，リスクや損害に関する情報が 多くなることは，放射線の危険性に対する認識が深まる ことを前提としており, 場合によってはその危険性に過 剩な反応を生じる原因になる可能性も有している。

一般に，人の認知過程は，人に対する外界からの刺激 を処理する過程とあらかじめ持っている知識などに基づ いて解釈, 推論し決定する過程の二つの側面を有してい 
る2)。つまり，原子力・放射線に関連する事柄の理解は， 新たに学んだ情報のみならず，これまでの知識や経験あ るいは期待によって決定される。したがって,これまで に安全性や危険性が偏って認識されていた場合，新たに 提供された情報の理解にゆがみを生じ，実際に生じる利 益や損害とはかけ離れて認知される可能性が高くなる。 こうした歪みは, 最終的には, 認知構造の変化を経てし だいに共通の理解へと接近するが3)，こうした認知過程 では知識情報, 即ち意味記憶やエピソード記憶として保 持されている記憶情報の在り方が重要な役割を果たすと 考えられている4)。

記憶情報の単位である概念はこれを特徵づける重み付 けされた多数の意味属性と関連づけられている5)。さら に，ある概念の意味属性は，それ自身が概念の単位とな り意味属性の新たな集合を形成し，概念のネットワーク 構造を形成する6)。人は身の回りの様々な事柄をこうし た概念のネットワーク構造に基づいて理解しているが, 原子力・放射線理解に関しても, 関連する諸概念とそれ らの関連性がその理解に深く関与していると考えられ る。こうした視点から, 本研究では, ある刺激語に対す る連想語の頻度分布に基づいて, 原子力・放射線の知識 がどのような概念とどのように関連付けられているの か, その構造を明らかにすることを試みた。さらに，こ こで得られた概念の関連性に基づいて，原子力・放射線 に対する理解をより促す可能性のある概念の形成につい て考察した。

\section{II 方 法}

\section{1. 平均的個人による概念の表現}

言語等によりある概念が刺激されると関連する概念が 想起され，それらの関連性の強さに応じて事柄の理解が 促される7)。しかし, 人の持つ概念は多様であり個人によ って異なる。また個人の概念はその重要性や想起の頻度 により質的あるいは量的に変化し, 相互の関連性の強さ も時々刻々と変化している。ここでは「個人の概念は所 属する集団の概念の多様性と特徵を反映する」 ${ }^{8)}$ と仮定 し，ある集団に属する個々人を構成要素とする平均的個 人を想定し，その集団の中に形成された概念の多様性と 関連性から, 平均的個人としての概念のネットワーク構 造を推定することにした。こうした平均的個人の考元方 を成立させるためには，集団の選択に関して，集団がひ とまとまりである何らかの共通項を有し，その集団を特 徵づける幾つかのパラメータが明確であり, 意識される ことの比較的少ない概念をある程度導き出しうる規模の
人数で構成されていることなどの条件を満たす必要があ る。さらに，社会現象の諸相を抽出による意見分布に基 づいて明らかにしょうとする社会調査では，特に対象集 団からの標本の採り方に偏りを生じないよう注意する必 要があるが9)，平均的個人を把握しようとする場合には 選択された集団それ自身が調査の対象となるため，集団 の構成員全員からの回答を得る必要があり，できるだけ 多様性を損なわないよう留意することが重要になる。平 均的個人はあるひとまとまりの集団の性質を示すもの で，その結論は一般化の可能なものも含むが，多くは選 択された集団が共有する特徵的な概念とその関連性を表 現したものとなる。このことは，逆に，適当な集団を選 択し平均的な個人を想定することで，ある集団の平均的 な概念の構造と他の集団のそれとの比較検討を可能にす るとともに社会現象と概念の構造変化との関連を明らか にできる可能性を有している。

\section{2. 調查の方法}

調査は, 何らかの刺激語が提示された場合, 関連性の 高い典型的な連想語が最も早く想起されることから7), ある刺激語を提示した後, 最初に連想する用語を 1 個記 述してもらう方法で行った。概念は必ずしも言語と一致 しないが，ここでは一般になされる哲学上の定義「概念 は言語とともに生れ，言語によって表現される」を前提 にして「概念は連想語によって表現さる」ことを仮定し た ${ }^{10)}$ 。最初の連想語のみを採用したのは，提示された刺 激語に対し被験者どおしの相互作用の無い状態での連想 語をできるだけ正確に把握することを考慮したものであ る。刺激語として提示した用語の一覧を Table 1 亿示 す。この調査では, エネルギー, 原子力, 放射線に関連 する連想語の相互の関連を知ることを目的とした。これ らの刺激語を提示する際には, 原子力や放射線と関連す ると思われる用語と直接関連しない用語を複数個同時に 提示することで，調查実施者の影響を緩和し，原子力・

Table 1 The terms prepared for the investigation on the structure of concepts concerning the use of atomic energy and radiation.

\begin{tabular}{|c|c|}
\hline 実 施 & 提示した用語 \\
\hline 2000 年 10 月 & $\begin{array}{l}\text { 地球, エネルギー, 経済, 発電, 輸送, } \\
\text { 生命, 情報, 安全, 資源 }\end{array}$ \\
\hline 2000 年 11 月 & $\begin{array}{l}\text { 環境, 成長, 原子力, 車, インターネ } \\
\text { ッ, 医療, 文明, 宇宙, 技術 }\end{array}$ \\
\hline 2001 年 1 月 & $\begin{array}{l}\text { 太陽光, 遺伝子組み替え, ビ夕ミン, } \\
\text { 放射線, } \beta \text { カロチン, ストレス, X 線, } \\
\text { アルコール, たばこ }\end{array}$ \\
\hline
\end{tabular}


放射線の調査を過度に強調したものにならないよう留意 した。また，概念の関連をより詳細に得るために比較的 意味の広い用語から次第に具体的なものになるよう考慮 して選択した。調查は，1 回目を 2000 年 10 月初旬に行 い，前回調査との繫がりの効果を少なくするために，以 後, 1 力月半程度の期間をおいて 2 回目, 3 回目を実施し た。

\section{3. 対象集団}

平均的個人を構成する集団として，ここでは福山大学 及び近畿大学の工学系学生を選択した。これらの学生集 団は，大学生一般や若者全般を表現するものでなく，平 均的個人の概念の関連性を類推するためのひとつの単位 として，また，集団の採り方によって同じ刺激語に対す る連想語に違いが生じるかどうかの検討のために調査対 象として選択した。福山大学は広島県東部に位置し, 中 国，四国地方出身の学生が多い。対象とした学科は電子 電気工学科で，学年は 3 年生を中心とする約 60 名であ る。この学科の学生は一般教育課程を修了し 電子電気工 学の専門課程科目を履修中である。一方, 近畿大学は大 阪府東大阪市にあり, 近畿地方出身の学生が多数をしめ る。対象とした学生は原子炉工学科で, 学年は 2 年生を 中心とする約 60 名である。この学科の学生は専門課程 科目と平行して一般教育課程科目履修中のものが大半で ある。両集団の構成員は殆どが男性で, 数名の女性がい る点で共通している。

\section{4. 概念の関連付けの方法}

それぞれ提示された刺激語に対する連想語を近い意味 を有する概念に分類した後, 頻度分布として整理し，そ
の頻度の大きさで刺激語と連想語の関連性の強さを評価 した。また，一般には概念のネットワーク構造は多くの 階層を有する複雑な構造になると言われているが，ここ では概念相互の関連性の有無とそれらの強さを表現する ものとして，刺激語に対する連想語を平面的に配置し， 関連性に強さを線の太さで表現した。なお，刺激語に対 する連想語が共通の概念を有する場合，これらの用語の 配置には立体性を考慮した。

\section{III 結 果 と 考 察}

\section{1. 生命や環境に関連する概念}

原子力や放射線と直接関係のない用語によって集団が どのような概念をどのように形成しているかを見るため に，「生命」および「環境」の刺激語によって想起され た連想語のうち上位 17 個の頻度分布を Fig. 1, Fig. 2 に それぞれ示す。縦軸は 60 名程度の対象者による想起頻 度を\%で示した。Fig.1の「生命」から想起される用語 は，「動植物」，「人間」，「誕生」や「いのち」などであ り,「大切な」と言う意識も強く表れている。また, 生命 は「医療」,「保険」の頻度が比較的高くなっており命を 守るためのシステムとの関連が示されている。また, Fig. 2 の「環境」では「森」「地球」「自然」などあるがまま の自然の姿が用語として想起されるとともに「污染」 「破壊」「環境問題」「温暖化」などの環境破壊と関連し た用語が強く想起されている。これら二つの刺激語によ り想起された連想語の頻度分布から，まず，Fig. 1 での 「赤ちゃん」と「誕生」を類似のものと考元，Fig. 1 の 「動植物」,「海」, Fig. 2 の「ダイオキシン」を別にする

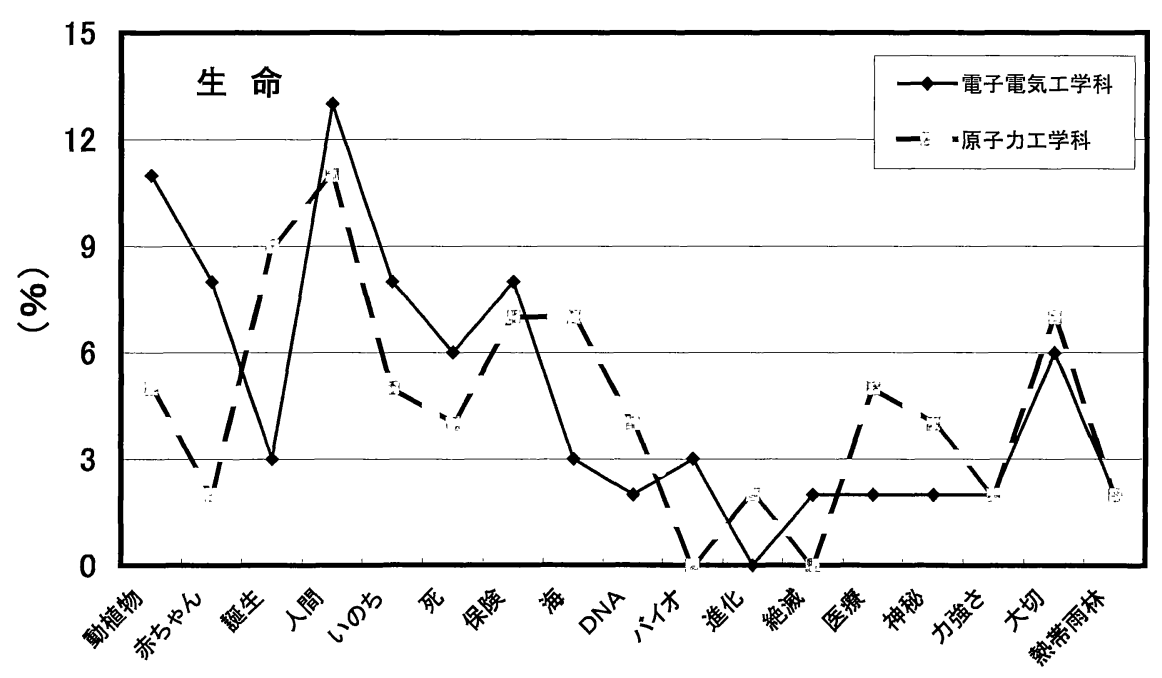

想起された概念

Fig. 1 The concepts reminded by the stimulus term of life. 


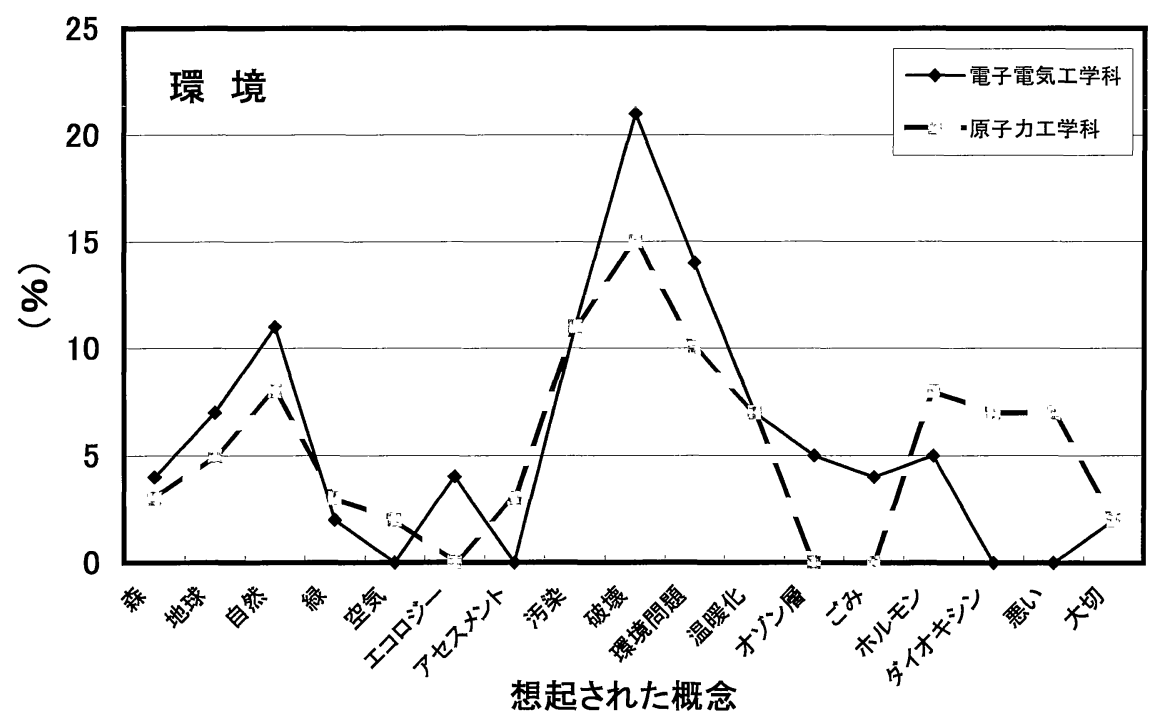

Fig. 2 The concepts reminded by the stimulus term of natural environment.

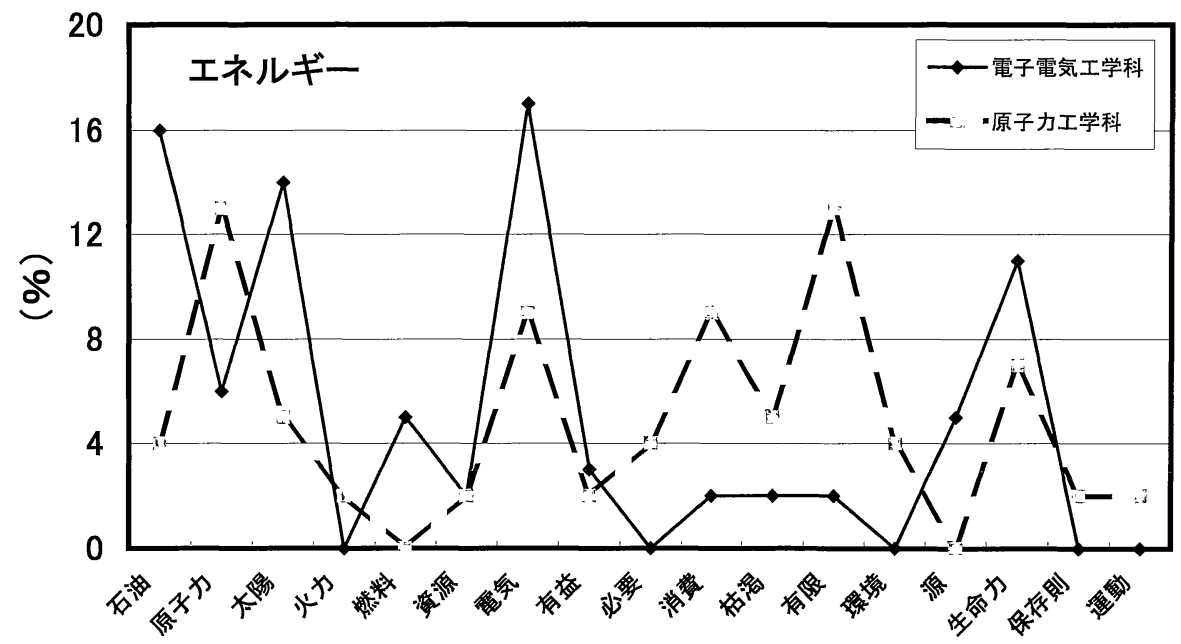

想起された概念

Fig. 3 The concepts reminded by the stimulus term of energy.

と，それぞれ想起される連想語の種類と頻度分布に両学 科学生に類似の傾向を見ることができる。即ち，対象と した二つの集団は概念の関連性について類似の構造をも つ可能性があり，「生命」や「環境」については，ある命 題に対して似通った判断を下す可能性を示唆している。 一方, 頻度分布の相違が顕著であった「動植物」と 「海」および「ダイオキシン」に関連して, 前者の二つの 概念は福山大学が比較的海岸に近く自然の多い環境に立 地していることを反映し, 後者は近畿大学が東大阪市で とり上げられたダイオキシン問題を身近な話題として理 解している可能性を示している。こうした考察が両者の 相違を全て説明しているとは言えないので, 頻度分布の
相違の有意性を判断するのは大変難しいが，ここでは 5 \%程度を超える頻度分布の相違には何らかの要因が作用 している可能性が考えられる。

2. エネルギー, 発電, 原子力に関連する概念

「エネルギー」, 「発電」, 「原子力」によって想起された 概念を Fig. 3〜Fig. 5 にそれぞれ示す。「エネルギー」で は, 「石油」,「原子力」,「太陽」等のエネルギー資源, あ るいは利用形態としての「電気」や資源の「消費」によ る「枯渴」と「有限性」が，更には人の持つ「生命力」 としてのエネルギーが高い頻度で想起されている。両学 科学生の比較では, 原子炉工学科の学生が資源としての 「原子力」を強く想起するのに比べ, 電子電気工学科の 


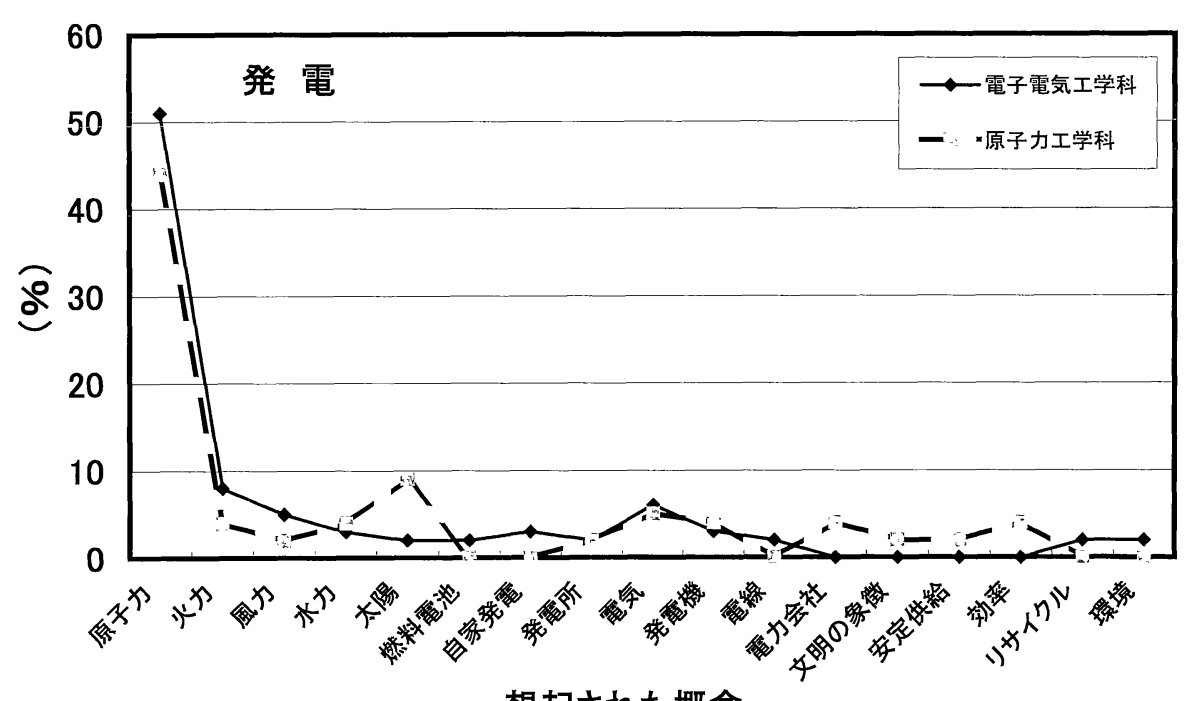

想起された概念

Fig. 4 The concepts reminded by the stimulus term of electric power generation.

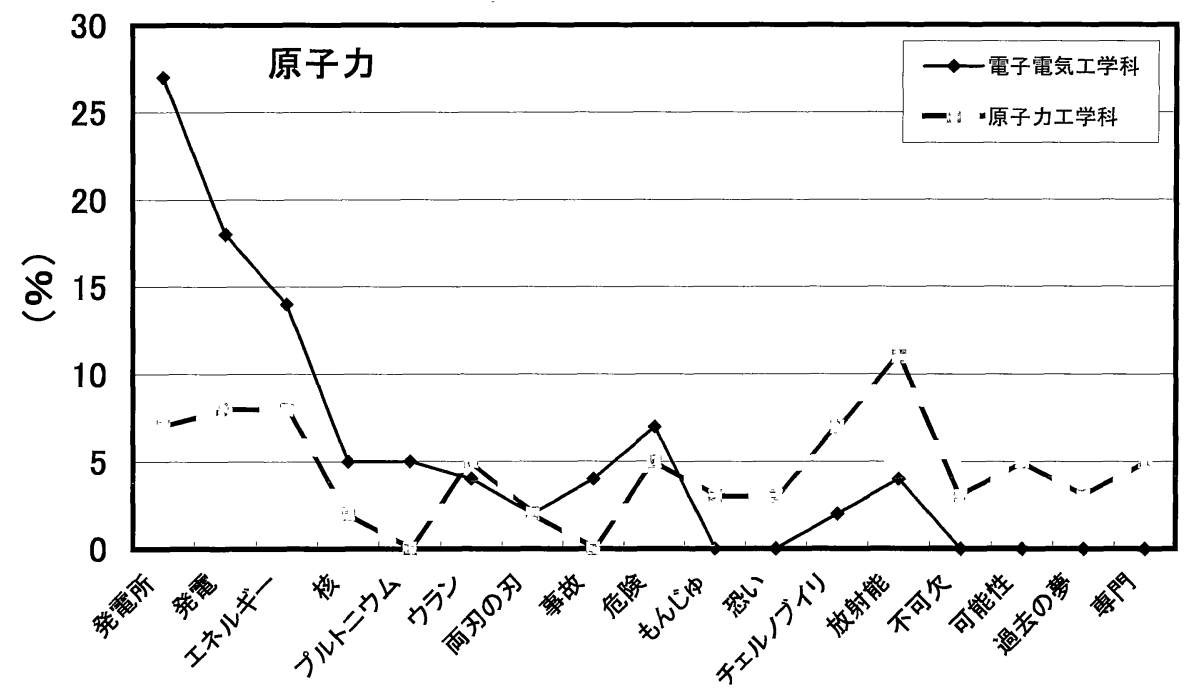

想起された概念

Fig. 5 The concepts reminded by the stimulus term of atomic energy.

学生が資源としては「石油」や「太陽」を強く想起し, さらに利用形態としての「電気」を強く想起するのは学 科の違いを反映したものと思われる。また, 原子炉工学 科の学生が「消費」,「枯渴」,「有限」等の概念を想起す るのは，原子力の問題が環境問題と関連付けて議論され る機会が多いことに起因すると考えられる。「発電」で は，発電のための資源（原子力，火力など）や発電技術 (発電所, 発電機, 電線など) に関連する用語が想起さ れ, 更には社会 (文明の象徵, 安定供給など) や環境 (リ サイクル，環境など）との関わりに関連する用語がわず かではあるが想起されている。「発電」に関連して特長 的なのは原子炬工学科学生とともに電子電気工学科学生
の約半数が「原子力」と答えていることである。このこ とは,「発電」と「原子力」の関連が学生の専門性に関 わりなく強く関連付けられていることを示し，その他の 集団でもこの関連性については期待できると思われる。 また,「発電」が「太陽」と関連付けられる頻度が原子 力工学科の学生で比較的高くなっているのは, 以下に見 るように，彼らが原子力の否定的な側面について多くの 知識を得たことを反映した可能性も考えられる。「原子 力」では, 電子電気工学科学生には「発電」, 「発電所」, 「エネルギー」などの電力としての「原子力」が強く想 起されるが，原子炉工学科の学生には同時に「放射能」 のイメージも強く表れている。また, 原子力は「可能性」 


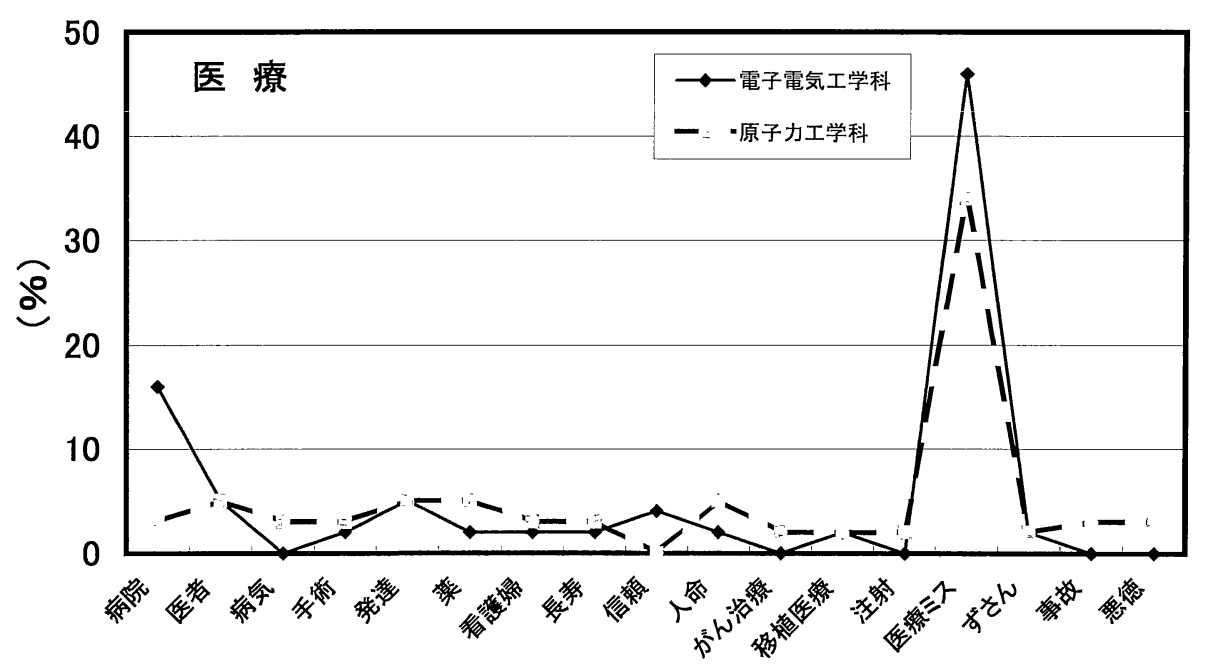

想起された概念

Fig. 6 The concepts reminded by the stimulus term of medical service.

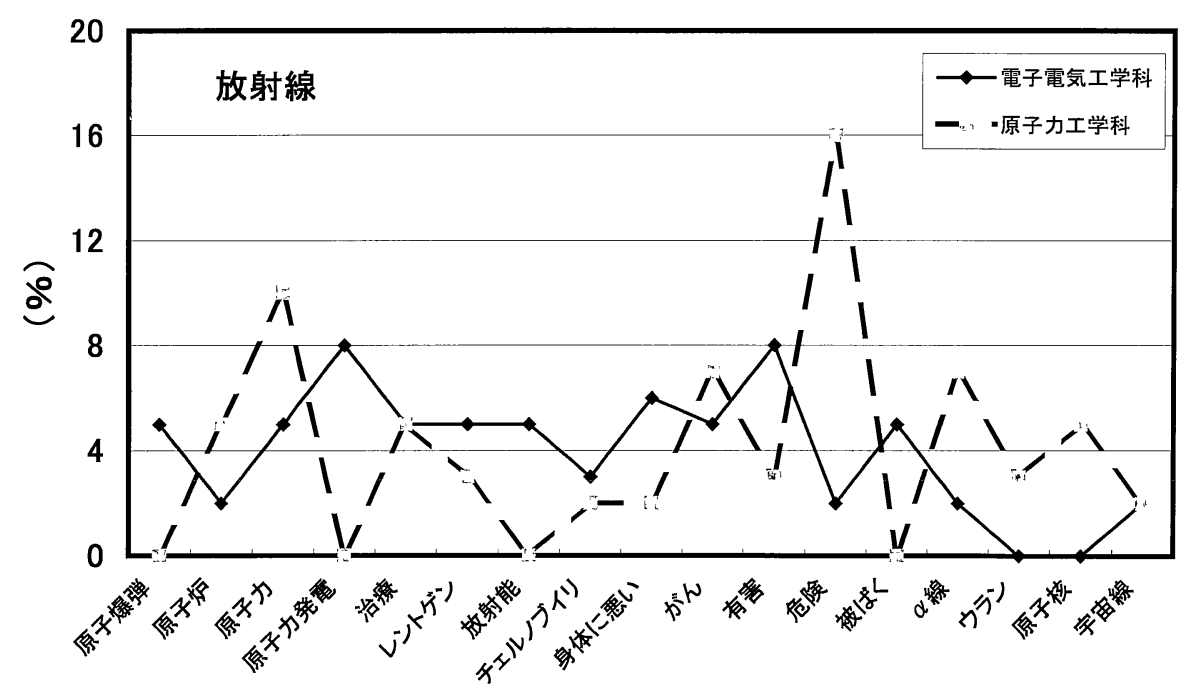

想起された概念

Fig. 7 The concepts reminded by the stimulus term of radiation.

であり「夢」であるとともに「事故」,「危険」,「チェル ノブイリ」等の事故に伴う危険性も想起されている。原 子力はエネルギー源として有効であり期待の持てるもの であるが重大事故による放射能污染が長期にわたること も強く印象に残されていることが伺われる。

\section{3. 医療，放射線に関連する概念}

「医療」，「放射線」によって想起された用語を Fig. 6, Fig. 7 にそれぞれ示す。「医療」では「病院」,「医者」, 「看護婦」,「薬」そして「手術」「発達」「がん治療」等 の医療技術のほかに「信頼」,「人命」,「医療ミス」,「事 故」などの用語が想起されている。「医療」に関して特 長的なことは,「医療ミス」が両学科の学生に共通に高
頻度で想起されることで, 医療ミスや「悪徳」医師の話 題が全国的に増え, 医療に対する従来の信頼が大きく崩 れつつある現実を示した可能性もある。「放射線」では 「原子力」や「原子力発電」の他に「治療」や「レント ゲン」が比較的高頻度で想起される以外には「がん」, 「有害」,「危険」などの身体への悪影響に関連する用語 がよく想起されている。また，原子力工学科では基礎的 な概念としての「 $\alpha$ 線」や「原子核」，自然放射線とし ての「宇宙線」が想起されるのも特徴的である。これら の結果から, 原子炬工学科学生が原子力や放射線の基礎 的事項（原子炉， $\alpha$ 線，原子核など）に関する用語を比 較的多く回答する反面, 放射線に対する危険意識も同時 


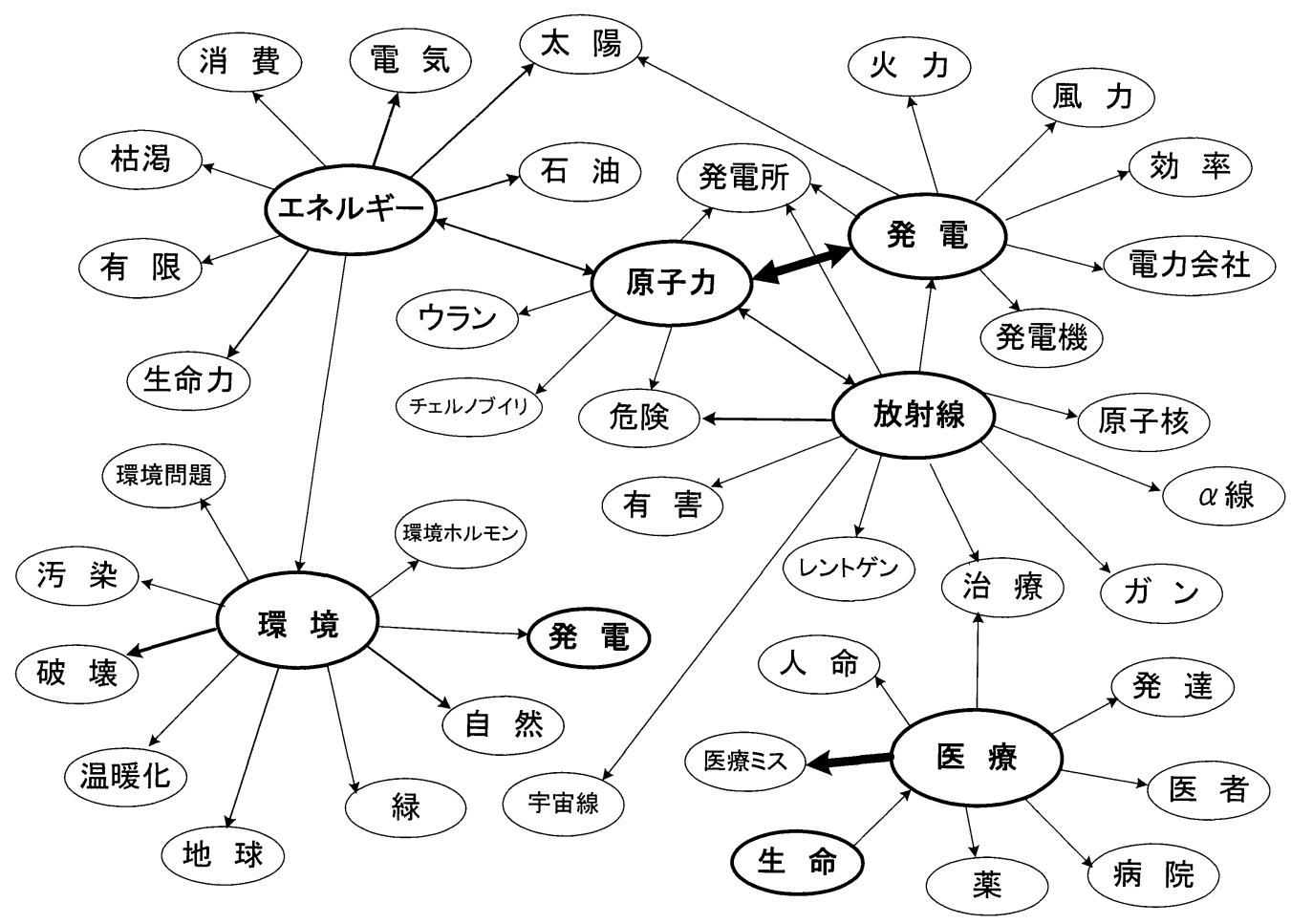

Fig. 8 A relevance of the concepts reminded by stimulus terms concerning energy, atomic energy, and radiation.

に強いことが明らかである。このことは，これまでも言 われてきたように，専門的知識の量の増加が必ずしも安 全や危険の判断に結びつかないことを示している11)。こ うした傾向を明らかにするには科学的リテラシーの高さ やコミュニケーションの在り方と理解度の促進との関連 性についてさらに詳しく検討する必要がある。また,「放 射線」では電子電気工学科の場合,「原子爆弾」との関 連性が見られるが，太田も指摘するようにここでも放射 線被ばくと原爆の関連性が認められる ${ }^{12)}$ 。全般的に，「放 射線」では有益性よりも有害性に関連する反応語の方が より強く想起されるが，この原因としては放射線の有用 性に関する情報より放射線の危険性がマスコミ等で頻繁 に取り上げられることとも関連していると考えられる。 $\mathrm{X}$ 線撮影の受容性は便益性を教えることで改善される ことが明らかにされておうり ${ }^{13)}$ ，放射線の理解にはその有 用性を宣伝することが極めて重要と思われる。

\section{4. 刺激語と連想語およびそれらの関連性}

刺激語とその結果想起された連想語（連想概念）の幾 つかを Fig. 8 に示した。ここでは特に「エネルギー」, 「原子力」，「放射線」によって想起された概念とそれら の関係を示した。図中で，調查のために提示した概念は 太い線で囲っている。また，刺激語と連想語の関連性の 高さはそれぞれの概念を結ぶ線の太さ（頻度の高さ）で
示している。今回の調査では，「エネルギー」，「原子力」， 「発電」の概念が相互に深く関わり，特に「原子力」と 「発電」が相互に強い関連性を有していること，「原子 力」は「エネルギー」と「発電」の両方の概念を経由し て環境とも深い関連を有していること，さらに，「放射 線」は「原子力」や「発電」のみならず「治療」の概念 を経由して「医療」「生命」などの概念と結びついてい ることなどが明らかである。一方で，「放射線」の概念 は，「原子力」，「レントゲン」「治療」以外では「危険」, 「有害」,「ガン」との関連性が強く, 危険なものとして理 解される傾向が他に比べ著しいこと，さらに，身近な放 射線としての自然放射線は「宇宙線」が想起されている が，「環境」によって想起される概念にも自然放射線に 関連する概念が見られないことから自然放射線が調査対 象学生に充分理解されていないことが伺われる。

以上の概念の関連性の検討から，環境を論じながら原 子力を理解することと環境を論じながら放射線を理解す ることには隔たりがあり，前者にはエネルギー利用とい う便益の明らかな概念が前提になるのに対し，後者には これらを介在する概念に欠け，例元ば，「原子力施設周辺 で施設に起因する放射線の線量は自然放射線の変動の範 囲以内である」と言う説明も，「 $\mathrm{CO}_{2}$ 削減対策のために 原子力利用は有効である」との説明ほど説得力をもたな 
い可能性が考えられる。放射線を理解するには幅広い知 識が必要となるが，自然放射線が「環境」と「放射線」 を理解する掛け橋になる可能性が高いことから，少なく とも「自然放射線」の概念を形成すべく身近な放射線に ついて，日ごろからよく情報を提供しておくことが重要 と思われる。

\section{IV おわりに}

原子力・放射線関連用語による刺激語と連想語の関連 性を検討した結果，以下のことが明らかとなった。

（1）原子力は「発電と言えば原子力」と言えるほど発 電との関連性が強い。

（2）原子力, エネルギー, 発電, 環境, の諸概念は相 互に深い関連を有している。したがって, エネルギ 一や環境問題と関連して原子力の理解を促すこと は可能である。

（3）放射線は原子力や医療と深い関連を有するが, 人 への影響に関しては否定的な概念との関連が強く, 有益な利用についてよく理解されているとは言い がたい。また，放射線に関連する基礎的事項を多く 知ることが安全や危険の判断に直接結びついてい る可能性は小さい。

（4）自然放射線に関連する概念は，放射線とのつなが りで「宇宙線」が想起されるが，多くの自然放射 線については日常的に接する身近な概念として形 成されるには至っていない。

本調査を実施するに当たって, 近畿大学理工学部原子 炉工学科小川喜弘講師にご協力頂きました。記して謝意 を表します。

\section{参 考 文 献}

1) ICRP; 1990 Recommendations of the International Commission on Radiological Protection, ICRP Publ. 60, Ann. ICRP, 21(1-3) (1991).

2) 御領 謙, 菊池 正, 江草浩幸; “最新認知心理学へ の招待”, pp. 49-72 (1998), サイエンス社, 東京.

3）小嶋恵子：スキーマによる理解と学習, 波多野誼余 夫編；“認知心理学講座 4 学習と発達”, pp. 27-40
(1986), 東京大学出版会, 東京.

4) E. Tulving; "Elements of episodic memory," (1983), Oxford Univ. Press, Oxford.

5) E.E. Smith, E.J. Shoben and L.J. Rips; Structure and process in semantic memory: A featural model for semantic decisions, Psychol. Rev., 81, 214-241 (1974).

6) A.M. Collins and M.R. Quillian; Retrieval time from semantic memory, J. Verb. Learn. Verb. Behav., 8, 240-247 (1969).

7) A.M. Collins and E.F. LofTus; A spreading activation theory of semantic processing, Psychol. Rev., 82, 407-428 (1975).

8）鈴木裕久, 堀 洋造 ; 社会的認知, 岡部慶三, 竹内 郁郎, 飽戸 弘編；“社会心理学”, (1988), 新曜社, 東京.

9）谷岡一郎；“「社会調査」のウソ リサーチリテラシ 一のすすめ”，(2000)，文芸春秋，東京.

10）森 宏一; 哲学辞典, (1972), 青木書店, 東京.

11）吉川肇子；安全目標とリスクコミュニケーション, 第33回原子力安全研究総合発表会講演論文, 原子力 安全研究協会, pp. 23-36 (2000).

12）太田勝正；放射線や被ばくという言葉から看護学生 は何を連想するか, Quality Nursing, 6(7), 585-590 (2000).

13）梅崎典良, 中村綾子, 坂本弘已, 宮川照生, 小野博 志，松本晴生，森田誠一郎，早㴊尚文；教育による 放射線に対する認識の変化, 日本放射線技術学会雑 誌, 55(4)，385-391 (1999).

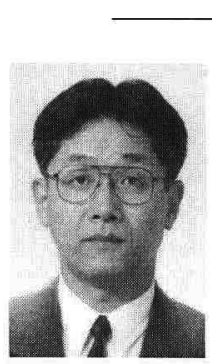

占部 逸正（うらべいつまさ）

1949 年広島県生れ。1974 年名古屋大 学大学院工学研究科修士課程修了。1975 年京都大学原子炉実験所入所。同所講 師, 福山大学助教授を経て, 1994 年より 同教授。この間, 主に自然及び作業環境 放射線の計測と線量評価の研究に從事。

E-mail: urabe@fuee.fukuyama-u.ac.jp 